IP Periodica Polytechnica

Transportation Engineering

47(1), pp. 19-24, 2019

https://doi.org/10.3311/PPtr.11192

Creative Commons Attribution (i)

RESEARCH ARTICLE

\section{Methodology for Tendering the Performances in Long Distance Rail Passenger Transport}

\author{
Jozef Gasparik $^{1^{*}}$, Pavol Mesko ${ }^{1}, Z_{\text {denka Zahumenska }}{ }^{1}$
}

Received 07 February 2017; accepted 11 July 2017

\begin{abstract}
A fundamental step in the liberalisation of the rail market has been the separation of the railway infrastructure from the railway operating. The partial liberalisation of the rail market in the European Union (EU) was already underway in 2010. Opening up the market to new private railway operators means that operators can compete for the performance of selected lines. The opening up process of domestic rail passenger transport markets according to the fourth railway package has a variety of levels in Member States. This process is requested to be performed not later than 2019, while making public tenders for transport service contracts compulsory in the public interest. The paper is focused on tender implementation steps for long-distance rail passenger transport and shows the legislation requirements for the tendering process. There is a need to analyse the technical and other obstacles and threats to the operation of long-distance rail services entering competition. The idea is to meet the objectives of the EU White Paper on transport and The Regulation (EC) No 1370/2007 of the European Parliament and of the Council of 23 October 2007 on public passenger transport services by rail and by road and repealing Council Regulations (EEC) No. 1191/69 and 1107/70.
\end{abstract}

\section{Keywords}

public tender, public interest, liberalisation of passenger transport

\footnotetext{
${ }^{1}$ Department of Railway Transport, Faculty of Operation and Economics of Transport and Communications, University of Žilina,

Univerzitná 1, 01026 Žilina, Slovakia

*Corresponding author, e-mail: jozef.gasparik@fpedas.uniza.sk
}

\section{Introduction}

The EU transport policy is based on the "White Paper on the Single European Transport Area - Creating a competitive, resource-efficient transport system' that includes forty initiatives to create an efficient transport system. The area of the allocation of public services includes an initiative to open up the domestic rail passenger market to competition, including the compulsory award of public service contracts through competitive tendering (Abramović, 2018). The rail transport market has undergone several transformations. These changes achieved the economic efficiency of rail transport, reducing the financial burden on the state budget, streamlining the management of the railway company and created the conditions for a market orientation. The aim is to increase the flexibility of rail transport to the needs of the customer. The requirements of liberalising the rail market and harmonizing the conditions for access to this market resulted in the adoption of the so called Fourth Rail Package. This package provides the obligation to tender public passenger transport services on the basis of the result of a fair public tender. In justified cases, public service performance in rail passenger transport is assigned by direct assignment for the selected railway undertaking (operator, carrier). This topic is analysed for example in the research of Mašek and Kendra (2013), and Kampf et al. (2012).

\section{Market opening legislation}

The basic secondary legislation, which provides for the allocation of public services is European Parliament and Council Regulation (EC) No. 1370/2007 on public service contracts by rail and by road from October 23, 2007 and Regulation (EU) No 2016/2338 of the European Parliament and of the Council amending Regulation (EC) 1370/2007 as it regards the opening of the services market national rail passenger service on 14 December, 2016 (Regulation (EC) No. 1370/2007).

This Regulation lays down the conditions under which competent authorities when imposing or contracting obligations arising from the public service provided by the suppliers pay for costs incurred and/or grant exclusive rights in return for fulfilling the obligations arising from the public service. The 
Regulation applies to national and international public passenger transport services in rail passenger transport, other passenger rail and road passenger transport. Exceptions are services which are provided mainly for their historical or tourist value (Regulation (EC) No. 1370/2007).

The amended version of the Decree from December 2016 introduced the definition of public service. It is done a public railway passenger transport where they concern transport by rail, with the exception of other track-based modes such as a metro or tramways. Public service performances are provided by a public or private undertaking for passengers or carriers on the basis of a public service contract concluded between the railway undertaking and the competent public authority or authority with such competence. This authority in the concerned Member State has the right to interfere with public passenger rail transport (Regulation (EC) No. 1370/2007).

Contracts are awarded either directly to a selected railway undertaking over which a competent authority has control or via other possible ways. The competent authority decides itself to provide services in the context of public services in railway passenger transport, and these performances are entrusted to a third party by tender (Camaj et al., 2015). The procedure adopted for competitive tendering shall be open to all operators, shall be fair and shall observe the principles of transparency and non-discrimination. Following the submission of tenders and any preselection, the procedure may involve negotiations in accordance with these principles in order to determine how best to meet specific or complex requirements. If subcontracting takes place, the operator entrusted with the administration and performance of public passenger transport services in accordance with this Regulation shall be required to perform a major part of the public passenger transport services itself (Cerna et al., 2016). A public service contract covering at the same time design, construction and operation of public passenger transport services may allow full subcontracting for the operation of those services. The public service contract shall, in accordance with national and Community law, determine the conditions applicable to subcontracting (Regulation (EC) No. 1370/2007, Commission staff working document accompanying the White Paper - Roadmap to a Single European Transport Area).

The direct awarding of rail passenger transport services (also for long distance lines) is possible if their estimated average annual value is less than $€ 7.5$ mil. or their range would be less than 500,000 kilometres per year. If the term of validity of the awarding does not exceed 10 years, the Contracts relating to rail passenger transport (excluding metro and tram) may be directly awarded (Peceny et al., 2016).

The validity of public service contracts in rail passenger transport which are not specified above does not exceed 15 years. The validity may be extended by a maximum of $50 \%$. For example, as in the case of a contract that is entered directly. These are depreciation conditions or reasonable costs resulting from a specific geographic location. It is then possible to extend the treaty to a maximum of $50 \%$ in the outermost regions. If justified by the amortisation of capital in relation to exceptional infrastructure, rolling stock or vehicular investment and if the public service contract is awarded in a fair competitive tendering procedure, a public service contract may have a longer duration. In order to ensure transparency in this case, the competent authority shall transmit to the Commission within one year of the conclusion of the contract the public service contract and elements justifying its longer duration (Regulation (EC) No. 1370/2007, Annex to the Position Paper, 2012).

Table 1 Comparison of the essential requirements according to their assignment

\begin{tabular}{|c|c|c|c|}
\hline \multirow{2}{*}{\multicolumn{2}{|c|}{$\begin{array}{l}\text { Requirements } \\
\text { Direct award }\end{array}$}} & \multicolumn{2}{|c|}{ How to enter the contract } \\
\hline & & Public tender & \\
\hline \multicolumn{2}{|c|}{$\begin{array}{l}\text { Maximum average annual value of } \\
\text { performance }\end{array}$} & up to $€ 7.5 \mathrm{mil}$. & Not specified \\
\hline \multicolumn{2}{|c|}{$\begin{array}{l}\text { Maximum annual amount of } \\
\text { performance }\end{array}$} & $\begin{array}{l}\text { up to } 500,000 \\
\text { kilometres }\end{array}$ & Not specified \\
\hline \multicolumn{2}{|c|}{ Maximum time of the contract } & 10 years & 15 years \\
\hline \multirow{3}{*}{$\begin{array}{l}\text { Opportunity and } \\
\text { reason for the } \\
\text { extension of the } \\
\text { Contract }\end{array}$} & $\begin{array}{l}\text { Depreciation of } \\
\text { assets }\end{array}$ & $\begin{array}{l}\text { yes, maximum up } \\
\text { to } 50 \%\end{array}$ & $\begin{array}{l}\text { yes, maximum } \\
\text { up to } 50 \%\end{array}$ \\
\hline & $\begin{array}{l}\text { Geographical } \\
\text { location }\end{array}$ & no & $\begin{array}{l}\text { yes, maximum } \\
\text { up to } 50 \%\end{array}$ \\
\hline & $\begin{array}{l}\text { Amortization of } \\
\text { the capital }\end{array}$ & no & $\begin{array}{l}\text { yes, necessary } \\
\text { justification }\end{array}$ \\
\hline \multicolumn{2}{|c|}{$\begin{array}{l}\text { Obligation to publish a pre- } \\
\text { announcement in the EU Bulletin } \\
\text { for an output range of } 50,000 \\
\text { kilometres or more }\end{array}$} & $\begin{array}{l}\text { yes, } 1 \text { year before } \\
\text { direct awarding }\end{array}$ & $\begin{array}{l}\text { yes, } 1 \text { year } \\
\text { before } \\
\text { starts public } \\
\text { tendering }\end{array}$ \\
\hline
\end{tabular}

The competent authority shall take measures to be able to publish in the Official Journal of the EU, its identification data (at least the name and address) for at least a year before the launch of the invitation to tender procedure or one year before the direct award. They are also required to disclose the type of award. Also, the services and areas that are to be subject to the Agreement must also be disclosed, and the planned date when they want to apply the Services Agreement in the interest of their own. Should this information change after its publication, the competent authority shall publish an amendment accordingly as soon as possible. This obligation does not apply to public service activities less than 50,000 kilometres per year. The competent authority is required to publish within one year the name of the contracting carrier (or bodies performing inspection), the term of the contract description provided service for rail passengers and the parameters of financial compensation, the quality objectives (accuracy, reliability), rewards or penalties and the conditions on major assets. The competent authority shall publish all this, in the case of a direct award of public service contracts (Regulation (EC) No. 1370/2007). 
The competent responsible authority may require the railway undertaking to comply with certain qualitative and social and emission standards or criteria relating to specific public passenger transport services in rail passenger transport. These standards / criteria must also be published in both the tender documents and the public service contract (Cerna et al., 2016; Stopka et al., 2016).

The comparison of the basic requirements for long-distance rail passenger transport contracts according to the way they are entered are dealt with in Table 1.

\section{Proposal of a procedure for awarding performance in long-distance transport}

The basis for the proper and flawless functioning of public tenders not only in long-distance rail passenger transport is the determination of partial activities related to the provision of public tenders and competencies, particularly bodies responsible for these activities. In the process, it is necessary to determine the subject of the competition itself, the requirements and conditions that the winning carrier will have to meet and also to determine the course of the competition.

The sequence of partial activities in the proposed procurement methodology for long-distance rail transport operations is shown in the flowchart in Fig. 1. The individual activities will be carried out by the responsible entities according to the determined rules.

As the responsible entity for the preparation of the tender, its declaration and the selection of the winning carrier, we suggest the national transport ministry or other responsible transport authorities, e.g. a national or a co-ordinating body for public passenger transport. This entity will therefore be the body the orders the public service performance in railway passenger transport and among its main tasks will be:

- definition of long distance lines,

- defining the performance and quality requirements for individual items of the public tender, above all the determination of the cycle on long-distance lines of railway passenger transport, range of traffic in train kilometres, quality requirements and equipment for railway rolling stock and so on,

- reviewing the capacity of the lines, the availability of additional and secondary infrastructure services in cooperation with the Infrastructure Manager (e.g. traction current, technical inspection of rolling stock, travel ticket sales services and so on),

- construction of draft train traffic diagram for the period of validity of the public service contract,

- determining the requirements and conditions of the tender that the winning operator must meet,

- on the basis of the established timetable, in cooperation with the infrastructure manager, to identify the necessary infrastructure measures in the field of infrastructure to ensure the implementation of the required timetable,
- the publication of the advance notice and the preparation of the tender documents and the determination of the evaluation criteria and their priority,

- receiving and evaluating applications for participation,

- evaluation of offers and selection of the most advantageous offer according to established criteria,

- concluding a public service contract with the selected tenderer and evaluating its performance.

Before the start of a call for tenders, appropriate preparation is required. Concerned lines will be classified into three groups depending on the need to implement infrastructure measures:

- where no measure is required,

- implemented infrastructures measures not exceed a period of three years,

- implemented infrastructures measures that exceed a period of three years.

In some cases, regional rail lines can also be included in the public tender for the integrated transport system.

Quality requirements for rolling stock and the quality of the services provided must be processed in accordance with the requirements of quality standards - EN 13816 and EN 15140.

The announcement must also include the intended way of evaluating the candidate offers (determination of assessment criteria and weightings), information on the possibility of subcontracting or bidding by a group of carriers, information on specific conditions for foreign candidates, location and delivery of requests to participate and offers (in writing/ electronically), in which language, formalities of the application and tender) and the time limit for the submission of requests to participate and offers.

In the tender documents, other elements need to be included such as the terms of tariff integration, adjustment of fare, business and payment terms related to the contract, the need to provide a bank guarantee by the winning carrier for the performance of the contract, the method of processing the bid price, requirements of the tender offer, bid opening information, the deadline for submission of tenders and the possible duration of the bids, reservation of the rights of the customer, all possible annexes to the tender documents and other appropriate additional information according to the subject matter of the tender.

On the basis of the Regulation, a prior notification of the public tender must be published in the EU Bulletin at least one year before the start of the public tender. In addition, a prior notification will be published according to national rules within specified deadlines.

The preferred tendering procedure is a narrower competition. For the beginning of the public tender, the public tender statement notice will be published according to national rules, also a notification in the EU Bulletin (notifications contain the above-mentioned requirements). At this point, the candidates 


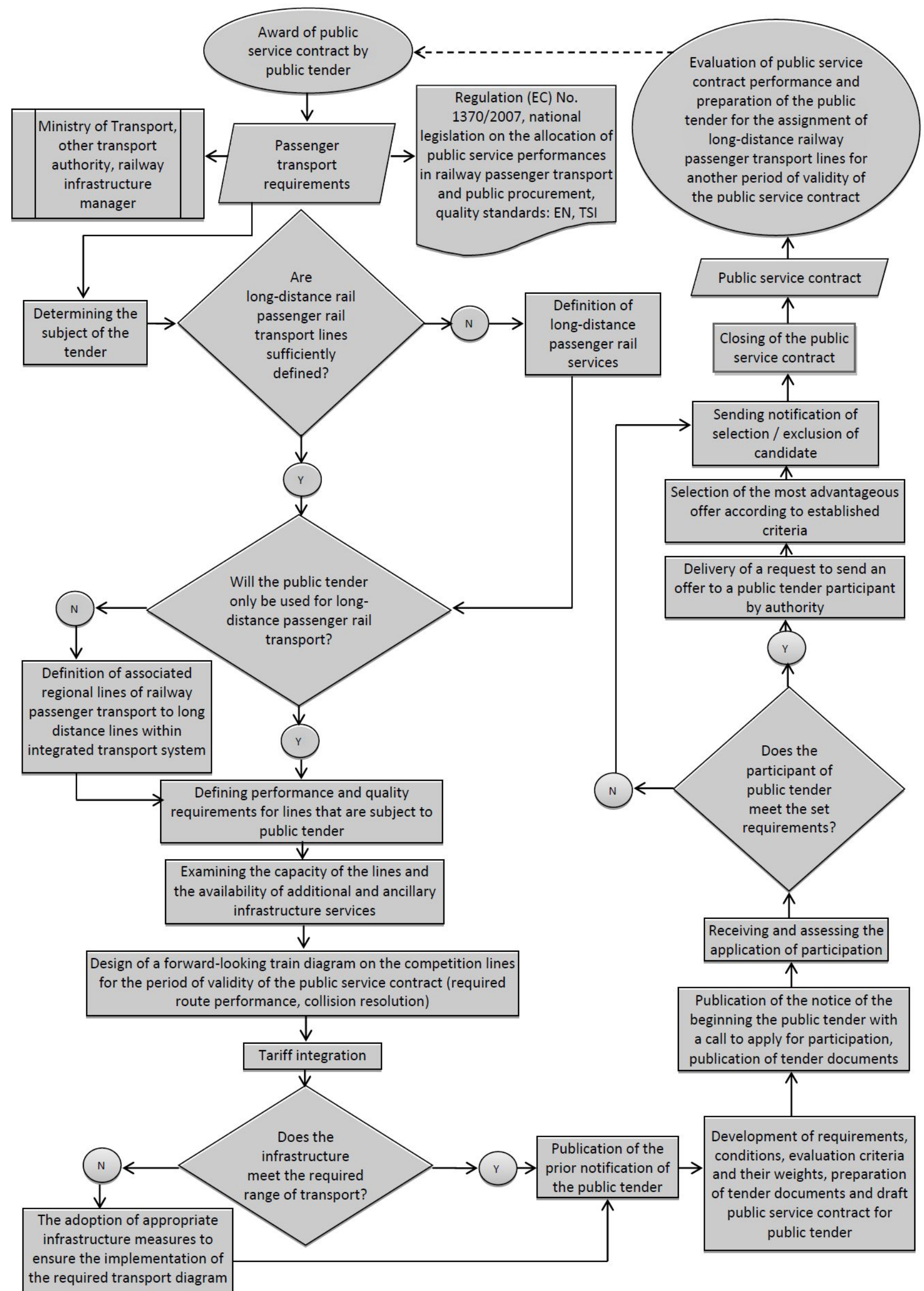

Fig. 1 Flowchart for the performances in long-distance rail passenger transport tender 
can send requests for participation in the public tender, which will be considered by the order body - unfit candidates will be sent a notice of exclusion from the public tender and satisfactory candidates will receive a request to send an offer within the specified time limit. After the deadline for submission of offers, the order body may open offers and choose the most advantageous offer within the specified timeframe in respect of the specified criteria. The selection of the winning rail operator shall be notified to all participating operators submitting offers by notice of operator selection. If there is no objection by the candidates or the winning operator, after completion and approval of the public service contract by both contracting parties, it may be concluded and subsequently fulfilled.

During the public tender, it will be possible to lodge objections on the part of the participants in the event of suspected violation of non-discriminatory access in the public tender, and the decision on the merits of the objections and the eventual cancellation of the public tender will be governed by the relevant national legislation.

Each contract must contain a clear definition of the obligations arising therefrom, and which have been established by the competent authority. It must also contain assigned geographical area; the parameters for calculating payment for public service performance and possible exclusive rights. The methodology for determining the cost associated with the provision of services such as performances in the public interest (in particular the costs of staff, energy, infrastructure, maintenance and repair of vehicles used in the security of public services, fixed costs and a suitable return on capital) must also be specified in the contract.

Contracts that are directly awarded also contain performance requirements such as the punctuality of services, frequency of train movements, quality of rolling stock, and transport capacity for passengers. The Provider is required in the Contract to provide the competent authority with the information necessary for the award of the Public Service Contract. The Competent Authority is required to make available all the relevant information that is necessary for the preparation of a tendering procedure for all interested parties to ensure the legitimate protection of confidential business information (e.g. information on passenger demand, fare, freight and revenue in public passenger transport covered by Public tender and detailed information on infrastructure specifications). The aim is to enable parties that are interested in the opportunity to develop good business plans (Position (EU) No. 19/2016, Commission staff working document accompanying the White Paper - Roadmap to a Single European Transport Area).

If the rolling stock is made available to a new public transport operator, the competent authority shall include in the tender documents any available information about the cost of maintenance of the rolling stock and about its physical condition
(Position (EU) No. 19/2016). Within this work the evaluation criteria and their weightings are specified, which can be used in the evaluation of the tender offers. However, it is important to always use the same assessment criteria and their weights for each public tender. The proposed assessment is to be carried out as a multi-criteria assessment, where the weightings of the individual criteria are as follows:

- required unit compensation by the operator for the first year of the validity of the public service contract at the price level of the current year [€/train kilometres] - $90 \%$,

- the variable component of the required compensation in the event of a change in the ordered transport performance at the current year price level [€/train kilometres] - $3 \%$,

- provide free Wi-Fi internet access - $1 \%$,

- $230 \mathrm{~V}$ power sockets for passengers - $1 \%$,

- the possibility of selling travel documents - $2 \%$,

- $1^{\text {st }}$ class seats available - $1 \%$,

- places for bicycle transport - $1 \%$,

- information provided to passengers through a visual information system - $1 \%$.

For each of the criteria, a number of points will be allocated to the candidate, calculated as the product of the points awarded and the determined weight of the criterion and the resulting number of points for the candidate will be obtained by the sum of the points earned by the individual criteria. Point allocation will be the responsibility of the Ministry, which will elaborate their detailed rules and will be published in the tender documents for the submission of offers.

The timetable for the public tender implementation will be different for each proposed group of long-distance lines, respectively specifically public tender objects, and may consist of the following phases:

- preparatory phase - definition of lines and subjects of each public tenders, review of the state of the infrastructure, construction of draft train traffic diagram, determining the requirements and conditions of the public tender, determining the extent of the necessary measures,

- the phase of measures - the implementation of the necessary measures,

- phase public tender - publication of the pre-notification, preparation of the tender documents and evaluation method, including the proposal of the public service contract, start of the public tender, reception and assessment of requests to participate and delivery of requests to submit an offer, receiving and assessing offers, selecting a winning carrier and delivering a carrier selection notice,

- finalisation phase - approving and closing the public service contract

- filling phase - performance of the public service contract. 


\section{Conclusion}

Outsourcers tenders in the Member States may be at varying levels of state administration and can have varying conditions of operation of public tenders (due to the various networks of railways, eg. different traction power supply system used on railway lines, various signaling systems etc.). Requirements for safety and interoperability must be common to all Member States with regard to the common EU legislation and technical specifications for interoperability (TSI).

The proposal for a methodology for the tendering of performances in long-distance railway passenger transport will help to create a uniform procedure for the operation and functioning of the public tender for railway passenger transport.

The key is the definition of successive steps leading to the conclusion of contracts for public transport services for individual long distance lines, the identification of responsible entities and their activities, the method of determining the requirements and conditions of public tender and the process of the public tender itself. The aim is to provide high-quality public transport services at a reasonable price.

\section{Acknowledgement}

The paper is supported by the VEGA Agency under Project $1 / 0095 / 16$, 'Assessment of the quality of connections on the transport network as a tool to enhance the competitiveness of public passenger transport system'.

\section{References}

Abramović, B. (2018). Infrastructure Access Charges. In: Marinov M. (ed.) Sustainable Rail Transport. Lecture Notes in Mobility. (pp. 45-58). Springer, Cham. https://doi.org/10.1007/978-3-319-58643-4_4

COMMISSION STAFF WORKING DOCUMENT Accompanying the White Paper - Roadmap to a Single European Transport Area - Towards a competitive and resource efficient transport system of 28 March 2011, KOM /2011/144. Brussels (2011). [Online]. Available from: http://eur-lex.europa.eu/legal-content/EN/ALL/?uri= CELEX:52011DC0144 [Accessed: 6th May 2017].

Camaj, J., Masek, J., Kendra, M. (2015). Possibility of applying the common queue of waiting for servicing railway passenger. In: Transport means 2015: proceedings, Kaunas University of Technology, 2015. pp. 147-151.
Cerná, L., Zitricky, V., Ponicky, J.(2016). Income and price elasticity of demand for transport services in rail passenger transport in the Slovak republic. In: Mathematical methods in economics = MME 2016: 34th: conference proceedings. Liberec: Technical University of Liberec, 2016. pp. 126-131.

European Committe for Standartization. (2002). EN 13816: Transportation. Logistics and services. Public passenger transport. Definition, objectives and measurement of quality of service.

European Conference of Ministers Of Transport, ECMT. (2007). Competitive Tendering of Rail Services. OECD Publishing, Paris.

Kampf, R., Gasparik, J., Kudlackova, N. (2012). Application of different forms of transport in relation to the process of transport user value creation. Periodica Polytechnica Transportation Engineering. 40(2), pp. 71-75. https://doi.org/10.3311/pp.tr.2012-2.05

Masek, J., Kendra, M. (2013). Experience in providing transport services in regional railway services by private railway undertakings. In: Regulated and unregulated competition on rails: Proceedings, Telc, Masaryk University, Brno. pp. 117-129.

Peceny, L., Gasparik, J., Gaborova, V. (2016). Development of public tender of paths ordering in long-distance rail transport in Slovak republic. In: ICTTE Belgrade 2016: Proceedings of the 3rd International Conference on Traffic and Transport Engineering ICTTE, Belgrade, Serbia, City Net Scientific Research Center, 2016, pp. 462-466.

POSITION (EU) No 19/2016 OF THE COUNCIL AT FIRST READING with a view to the adoption of a Regulation of the European Parliament and of the Council amending Regulation (EC) No 1370/2007 concerning the opening of the market for domestic passenger transport services by rail Adopted by the Council on 17 October 2016. (2016). [Online]. Available from: http://eur-lex.europa.eu/legal-content/ SK/TXT/PDF/?uri=CELE $\mathrm{X}: 32016 \mathrm{R} 2338 \&$ from=SK [Accessed: 6th May 2017].

REGULATION (EC) No 1370/2007 OF THE EUROPEAN PARLIAMENT AND OF THE COUNCIL No. 1370/2007 of 23 October 2007 on public passenger transport services by rail and by road and repealing Council Regulations (EEC) Nos 1191/69 and 1107/70, Strasbourg, (2007). [Online]. Available from: http://eur-lex.europa.eu/legal-content/en/ TXT/?uri=CELEX:32007R1370 [Accessed: 6th May 2017].

Stopka, O., Kampf, R., Vrabel, J. (2016). Deploying the means of transport within the transport enterprises in the context of emission standards. In: Transport means 2016: proceedings, Kaunas University of Technology, Kaunas, 2016. pp. 185-190. 